\title{
STRATEGI PENGEMBANGAN DESA TERTINGGAL DI NAGARI BATU BANYAK KECAMATAN LEMBANG JAYA KABUPATEN SOLOK
}

\author{
Elsa \\ Program Studi Pendidikan Geografi STKIP PGRI Sumatera Barat \\ Email: elsa.shan@yahoo.com
}

\begin{abstract}
Nagari Batu Banyak is one of the villages in West Sumatra. Weak physical and non-physical potential is thought to be a trigger lagging rural villages. For the purpose of this research is to determine the development strategy of backward villages in order to become a developed country. Qualitative research methods FGD (Focus Group Discussion) involving community leaders, cadiak pandai, and Wali Nagari. To reinforce the data, the researchers also conducted observations and interviews with informants. Appointment done by using purposive sampling while to determine rural development strategy using SWOT analysis (Strengths / strength, Weakness / weakness, Opportunities / opportunities, and Threats / threats) .Next, data analysis techniques through reduction, display, classification, and the conclusion. The result showed that the Nagari Batu Banyak an agricultural area with development potential persawahan.Belum type of physical and non-physical villages villages hamper progress. It can be seen from the acquisition of land resources are limited, damaged irrigation, and low production road access. While human resources, social institutions and economic institutions are still weak due to mental and public instant culture. Therefore, the strategy of rural development can be done by improving and optimizing natural resources through the use of quality seeds, improved irrigation and access roads production, improve the way the process of agriculture, improve human resources by training and counseling, socialization of economic action immoral, to improve the economy through the eyes of search Alternatively, set up a village granary, and to enhance community participation through social institutions.
\end{abstract}

Keywords: strategy, strategy development, backward village

\begin{abstract}
Abstrak
Nagari Batu Banyak merupakan salah satu desa tertinggal yang ada di Sumatera Barat. Lemahnya potensi fisik dan non fisik desa diduga menjadi pemicu tertinggalnya nagari. Untuk itu tujuan dalam penelitian ini adalah menentukan strategi pengembangan desa tertinggal agar menjadi desa maju. Jenis penelitian kualitatif dengan metode FGD (Focus Group Discussion) yang melibatkan tokoh masyarakat, cadiak pandai, dan Wali Nagari. Untuk memperkuat data, peneliti juga melakukan observasi dan wawancara dengan masyarakat.Penentuan informan dilakukan dengan menggunakan purposive sampling sedangkan untuk menentukan strategi pengembangan desa menggunakan analisis SWOT (Strengths/kekuatan, Weakness/kelemahan, Opportunities/peluang, dan Threats/ancaman).Selanjutnya, teknik analisa data melalui reduksi, display, klasifikasi, dan kesimpulan. Berdasarkan hasil penelitian diperoleh bahwa nagari Batu Banyak merupakan daerah pertanian dengan tipe persawahan.Belum berkembangnya potensi fisik dan non fisik
\end{abstract}


desa menghambat kemajuan nagari. Ini dapat dilihat dari perolehan sumberdaya lahan terbatas, irigasi rusak, dan akses jalan produksi rendah. Sedangkan dari sumberdaya manusia, lembaga sosial, dan lembaga ekonomi masih lemah akibat mental dan budaya instan masyarakat. Oleh sebab itu, strategi pengembangan desa dapat dilakukan dengan meningkatkan dan mengoptimalkan sumberdaya alam melalui pemakaian bibit unggul, memperbaiki irigasi dan akses jalan produksi, memperbaiki cara mengolah pertanian, meningkatkan sumberdaya manusia dengan pelatihan dan penyuluhan, sosialisasi tindakan ekonomi bermoral, meningkatkan ekonomi melalui mata pencarian alternatif, mendirikan lumbung padi nagari, dan meningkatkan partisipasi masyarakat melalui lembaga sosial. Kata kunci : strategi, strategi pengembangan, desa tertinggal

\section{PENDAHULUAN}

Desa tertinggal adalah daerah atau kabupaten yang relatif kurang berkembang dibandingkan dengan daerah lain dalam skala nasional. Indikator yang menjelaskan desa tertinggal erat kaitannya dengan bidang ekonomi (rendahnya standar hidup), sumber daya alam (SDA), sumber daya manusia (SDM), sarana dan prasarana, karakteristik wilayah (seperti lokasi dan keadaan geomorfologis), rawan bencana dan konflik, serta kebijakan pembangunan yang tidak mengikutsertakan desa atau sangat jauh dari pusat pembangunan wilayah. Walaupun kebijakan sudah banyak ditempuh dalam mengembangkan wilayah dan memprioritaskan pembangunan desa tertinggal dalam waktu yang sudah ditentukan, tapi tetap saja desa tertinggal masih tersebar di Indonesia (Keputusan Menteri Pembangunan Daerah Tertinggal No. 1 Tahun 2005).

Salah satu desa tertinggal yang ada di Kecamatan Lembang Jaya, Kabupaten Solok adalah nagari Batu Banyak. Nagari ini memiliki luas wilayah $878 \mathrm{Ha}$ atau $8,78 \mathrm{Km} 2$ yang terdiri dari tiga jorong yaitu jorong Lambah dengan luas wilayah $326 \mathrm{Ha}$, jorong Jambak $330 \mathrm{Ha}$, dan jorong Gobah 222 Ha. Sedangkan jumlah penduduk sekitar 2.469 jiwa atau 664 kepala keluarga (KK). Dilihat dari jumlah penduduk dan luas wilayah, maka kepadatan penduduk nagari Batu Banyak sekitar 281,21 jiwa/km2. Artinya setiap $1 \mathrm{~km} 2$ dihuni sekitar 281 jiwa penduduk sehingga dapat disimpulkan 
bahwa kepadatan penduduk di nagari Batu Banyak kategori sedang. Nagari Batu Banyak merupakan daerah perbukitan dengan variasi tingkat kemiringan lereng yaitu landai (54\%), agak curam (42\%), dan curam (4\%) (Kantor Wali Nagari, 2012).

Ketertinggalan nagari Batu Banyak tergambar dari keadaan potensi desa. Potensi desa adalah seluruh sumber daya yang dimiliki desa baik potensi fisik (tanah, iklim, ternak, manusia) maupun potensi non fisik (penduduk dan kelembagaan). Potensi ini digunakan untuk mengidentifikasi desa tertinggal yang diduga sebagai wilayah yang dihuni oleh penduduk miskin (Dirjen Pemberdayaan Masyarakat dan Desa, 2007:10). Di nagari Batu Banyak terdapat $77 \%$ rumah tangga miskin, $21 \%$ rumah tangga sedang, dan $2 \%$ rumah tangga mampu. Untuk lebih jelasnya dapat dilihat pada tabel 1 dibawah ini.

Tabel 1

Rumah Tangga Miskin di Nagari Batu Banyak

Tahun 2012

\begin{tabular}{|c|l|c|c|}
\hline No & Klasifikasi Rumah Tangga & $\begin{array}{c}\text { Jumlah dalam Kepala } \\
\text { Keluarga }\end{array}$ & $\begin{array}{c}\text { Persentas } \\
\text { e (\%) }\end{array}$ \\
\hline 1. & Rumah Tangga Miskin & 517 & 77 \\
\hline 2. & Rumah Tangga Sedang & 134 & 21 \\
\hline 3. & Rumah Tangga Mampu & 13 & 2 \\
\hline & Jumlah & 664 & 100 \\
\hline
\end{tabular}

Sumber : Program Nasional Pemberdayaan Masyarakat Mandiri Nagari, 2012.

Tabel 1 menjelaskan bahwa sekitar 77\% penduduk merupakan keluarga miskin atau 517 kepala keluarga berada dalam garis kemiskinan. Tingginya angka kemiskinan di nagari Batu Banyak membuktikan bahwa nagari ini termasuk kedalam kategori desa tertinggal. Rumah tangga miskin tersebar ke tiga jorong yaitu jorong Jambak (200 kepala keluarga), jorong Lambah (212 
kepala keluarga), dan jorong Gobah (252 kepala keluarga) (Program Nasional Pemberdayaan Masyarakat Mandiri Nagari, 2012).

Tingginya angka kemiskinan di nagari Batu Banyak dipengaruhi oleh sumber daya alam (SDA) yang terbatas. Berdasarkan jenis penggunaan lahan, nagari ini memiliki luas lahan sawah $438 \mathrm{Ha}$ (setengah dari luas wilayah), ladang kering $250 \mathrm{Ha}$, dan ladang tidur $20 \mathrm{Ha}$. Dari luas lahan sawah $438 \mathrm{Ha}$, sekitar 238 Ha merupakan sawah yang sudah tergadai ke nagari tetangga atau perantau dan hanya $200 \mathrm{Ha}$ luas lahan yang dimiliki masyarakat. Jika jumlah lahan dibagi dengan jumlah kepala keluarga $664 \mathrm{KK}$, maka masyarakat hanya memperoleh lahan sawah sekitar 0,4 Ha/KK. Dengan luas 0,4 Ha, diperoleh hasil produksi beras sekitar 500 liter dan jika diuangkan Rp.500.000,- /panen. Sedangkan panen padi dilakukan sekali 4 bulan atau 3 kali dalam setahun (Sumber : Profil nagari Batu Banyak, 2012).

Ditinjau dari sumber daya manusia, rata-rata tingkat pendidikan masyarakat Batu Banyak tergolong rendah. Berdasarkan data yang diperoleh sekitar 448 orang tidak tamat SD, 573 orang tamatan SD dan SMP, 83 orang tamatan SMA, dan 6 orang tamatan perguruan tinggi. Berarti sekitar 75\% tingkat pendidikan masyarakat merupakan tamatan SD dan SMP. Sedangkan koperasi unit desa (KUD) yang berbadan hukum tidak pernah terealisasi sampai sekarang karena minimnya pengetahuan masyarakat tentang arti dan fungsi koperasi. Selanjutnya, sarana dan prasarana yang minim juga mempengaruhi aspek pertanian, pendidikan, dan kesehatan. Keterbatasan irigasi mengakibatkan hasil pertanian tidak optimal. Apalagi sistem pertanian yang masih bersifat tradisional mengakibatkan produktivitas rendah (Sumber : Kantor Walinagari Batu Banyak, 2012).

Berdasarkan latar belakang masalah, maka perlu dilakukan strategi pengembangan nagari Batu Banyak agar menjadi desa maju. Sebab berdasarkan posisinya, nagari Batu Banyak terletak antara desa maju yaitu 
nagari Koto Anau dan Koto Laweh dengan akses yang lancar. Kelancaran aksesibilatas ini dapat memicu kemajuan desa jika dilakukan strategi-strategi pengembangan.

\section{METODE PENELITIAN}

Penelitian ini adalah penelitian kualitatif dengan metode FGD (Focus Group Discussion) yang melibatkan tokoh masyarakat, cadiak pandai, dan Wali Nagari. Adapun cara teknik pengumpulan data melalui observasi, wawancara (masyarakat) dan FGD dengan tokoh masyarakat yang paham dengan masalah nagari. Semua data yang berhasil dikumpulkan melalui FGD dan wawancara direkapitulasi, dibuatkan transkripnya setelah itu dianalisis. Analisa data ini menggunakan analisis SWOT (Strengths/kekuatan, Weakness/kelemahan, Opportunities/peluang, dan Threats/ancaman) dengan matriks yang nantinya akan menghasilkan strategi pengembangan yang tepat. Matriks ini dapat menghasilkan empat sel kemungkinan alternatif strategis, untuk lebih jelasnya dapat dilihat pada gambar dibawah ini :

\begin{tabular}{|c|c|c|}
\hline & $\begin{array}{c}\text { Kekuatan } \\
\text { (Strengths-S) }\end{array}$ & $\begin{array}{c}\text { Kelemahan } \\
\text { (Weaknesses-W) }\end{array}$ \\
\hline Peluang & Strategi SO & Strategi WO \\
(Opportunities-O) & Srategi ST & Strategi WT \\
\hline $\begin{array}{c}\text { Ancaman } \\
\text { (Threats-T) }\end{array}$ & & \\
\hline
\end{tabular}

Gambar 1. Matriks SWOT, Sumber : Wasistiono, dkk (2007:93)

Berdasarkan gambar dapat dijelaskan bahwa SO adalah memanfaatkan seluruh kekuatan dengan memperhatikan peluang, WO memanfaatkan kelemahan dengan memperhatikan peluang, ST adalah memanfaatkan 
kekuatan dengan memperhatikan ancaman, dan WT memanfaatkan kelemahan dengan memperhatikan ancaman.

\section{PEMBAHASAN}

\section{a. Letak, Batas, dan Luas}

Nagari Batu Banyak adalah salah satu nagari yang ada di kecamatan Lembang Jaya, Kabupaten Solok. Nagari ini berada pada ketinggian 600-750 mdpl. Secara astronomis, nagari Batu Banyak terletak pada 0 $033^{\prime} 40^{\prime \prime} \mathrm{LS}-$ 0 $55^{\prime} 55^{\prime}$ " LS dan 100 41'36" BT - 100 42'56" BT. Adapun batas-batas nagari Batu Banyak adalah sebelah utara berbatasan dengan nagari Koto Anau, sebelah selatan berbatasan dengan Koto Laweh dan Limau Lunggo, sebelah timur dengan nagari Batu Karak Dilam, dan sebelah barat dengan Koto Anau jorong Sawah Bukik. Nagari ini memiliki luas wilayah sekitar $878 \mathrm{Ha}$ yang terdiri dari tiga jorong yaitu jorong Lambah (326 ha), jorong Jambak (330 ha), dan jorong Gobah (222 ha).

\section{b. Curah Hujan, Topografi, dan Penggunaan Lahan}

Keadaan curah hujan rata-rata tahunan di nagari Batu Banyak berkisar antara $3.001 \mathrm{~mm} /$ tahun. Curah hujan ini kategori tinggi karena kelembapan udara yang tinggi. Secara umum, nagari ini memiliki tingkat variasi lereng yaitu landai (54\%), agak curam (42\%), dan curam (4\%). Tingkat variasi lereng ini dapat dilihat pada peta topografi lampiran 4. Sedangkan dalam penggunaan lahan di nagari Batu Banyak terdiri atas pemukiman, sawah, lahan kering, lahan tidur, dan kuburan. Untuk lebih jelasnya dapat dilihat pada tabel dibawah ini. 
Tabel 2

Luas dan Jenis Penggunaan Lahan di Nagari Batu Banyak

Tahun 2012

\begin{tabular}{|l|l|c|}
\hline No & \multicolumn{1}{|c|}{ Jenis Penggunaan Lahan } & Luas (Ha) \\
\hline 1 & Permukiman & 152 \\
\hline 2 & Sawah & 438 \\
\hline 3 & Ladang Kering & 250 \\
\hline 4 & Ladang Tidur & 20 \\
\hline 5 & Kuburan & 18 \\
\hline 6 & Jumlah & 878 \\
\hline
\end{tabular}

Sumber : Kantor Wali Nagari Batu Banyak, 2012.

Berdasarkan luas dan jenis penggunaan lahan di nagari Batu Banyak sekitar 152 ha adalah permukiman penduduk, 438 ha sawah, ladang kering 250 ha, ladang tidur 20 ha, dan kuburan 18 ha. Dari penggunaan lahan tersebut tergambar bahwa nagari Batu Banyak memiliki tipologi persawahan. Ini disebabkan karena sebagian besar penduduk hidup bergantung dari usaha pertanian khususnya sawah.

Menurut Suhardjo (2008:204), penggunaan lahan menunjukkan keterkaitan aktivitas manusia dengan sebidang lahan. Makna penggunaan lahan bagi perencanaan merupakan cerminan pemanfaatan sumber daya alam yang optimal, ekonomis, pemenuhan kebutuhan, menunjukkan keterampilan pengetahuan pengguna, dan menjelaskan ketersediaan sarana prasarana, modal, tenaga kerja, pemasaran, dan adaptasi terhadap masalah yang terjadi. Berdasarkan penggunaan lahan dapat diketahui dan diidentifikasi apakah wilayah mampu memanfaatkan sumberdaya yang dimilikinya secara optimal atau tidak. Penggunaan lahan menjelaskan kemandirian dan kreatifitas yang dimiliki masyarakat di dalamnya.

\section{Potensi Fisik Nagari Batu Banyak}

\section{a. Sumber daya lahan}

Potensi fisik nagari Batu Banyak khususnya sumberdaya lahan belum dimanfaatkan secara optimal. Ini disebabkan oleh rendahnya pengetahuan masyarakat dalam bidang pertanian dan penguasaan IPTEK. Kurang 
pahamnya masyarakat dalam bertani mengakibatkan hasil produksi rendah. Selanjutnya, status kepemilikan lahan yang merupakan milik kaum merupakan salah satu faktor terjadinya pembiaran lahan. Sedangkan kemiskinan yang membelenggu masyarakat mengakibatkan lahan sawah banyak tergadai ke nagari tetangga maupun masyarakat yang kaya di nagari tersebut sebab sawah merupakan modal utama yang dimiliki masyarakat dalam aktivitas ekonomi. Kompleksnya permasalahan nagari ini membuat masyarakat lupa akan potensi air yang dapat dimanfaatkan untuk budidaya ikan.

\section{b. Infrastruktur (Irigasi dan Jalan)}

\section{1) Irigasi}

Irigasi di nagari Batu Banyak bersifat sederhana sehingga berada dalam keadaan darurat, rusak, dan bocor. Keadaan ini mempengaruhi kedalaman dan lebar irigasi yang menjadi sempit dan dangkal. Kerusakan irigasi mengakibatkan distribusi air tidak lancar dan tidak merata ke sawah-sawah dan berdampak terhadap rendahnya hasil produksi pertanian. Kurang terpeliharanya irigasi disebabkan oleh sikap masyarakat yang kurang peduli terhadap lingkungan, misalnya sampah dibuang ke bandar sehingga menghambat laju air. Apalagi ada sebagian masyarakat yang hanya mementingkan kepentingan pribadi dibandingkan dengan kepentingan umum seperti sengaja meniriskan irigasi agar air sepenuhnya mengalir ke sawah pemiliknya.

\section{2) Jalan}

Menurut ketentuan Departemen Pekerjaan Umum dalam Koestoer (1995:126), jalan merupakan salah satu prasarana perhubungan dan komunikasi dari suatu lokasi ke lokasi lain. Kondisi jalan dapat menentukan baik atau buruknya tingkat aksesibilitas suatu wilayah.Di nagari Batu Banyak kondisi jalan sentra produksi masih sangat jelek yaitu jalan setapak dengan 
permukaan tanah yang mengakibatkan upah angkut menjadi mahal. Ditambah lagi keadaan topografi yang curam semakin mempersulit petani. Selanjutnya, ada empat jalan menuju sentra produksi yang harus dibuat atau diperbaiki yaitu Parak Pakia-Siamban-Jambu Balirik (2 km), MandailiangSawah Piriang-Pincuran Batu-Lurah Batu Gadang (2,5Km), Pintu RayoKayutanam-Sungai Badak (1 km), dan Kelok Dama-Batu Kasek-Guguak Siamang-Limau Asam (2,5 km). Akses jalan produksi ini perlu dibina dan direhabilitasi sehingga masyarakat khususnya petani tidak kesulitan dalam aktivitas yang berhubungan dengan pertanian.Mengingat kegiatan masyarakat lebih banyak bergerak dibidang pertanian.

\section{Potensi Non Fisik Nagari Batu Banyak}

\section{a. Sumberdaya manusia}

Sumberdaya manusia merupakan potensi yang dimiliki manusia dan digunakan seoptimal mungkin untuk kelangsungan hidup. Kualitas sumberdaya manusia diukur dari tingkatan pendidikan yaitu SD, SMP, SMA, dan perguruan tinggi (PT). Pendidikan merupakan usaha dalam meningkatkan kecerdasan dan keterampilan masyarakat. Tanpa memperhatikan tingkat pendidikan, maka sebuah wilayah akan kacau dan tertinggal karena pendidikan merupakan kunci utama dalam mencapai kesuksesan hidup. Sedangkan kuantitas manusia dilihat dari jumlah dan persebaran penduduk.Nagari Batu Banyak memiliki kualitas sumberdaya manusia yang rendah akibat dari kemiskinan, minimnya pemahaman masyarakat tentang arti penting pendidikan sehingga masyarakat berpendapat bahwa pendidikan merupakan alat untuk mempertajam kelas sosial seseorang dan hanya untuk menghabiskan uang saja. Rendahnya kualitas manusia mengakibatkan tingginya angka ketergantungan masyarakat terhadap hasil produksi (sumberdaya alam) karena tidak memiliki keterampilan lain selain ke sawah. 


\section{b. Lembaga Sosial}

Lembaga sosial merupakan pedoman bagi masyarakat dalam meningkatkan kesejahteraan hidup. Di nagari Batu Banyak lembaga sosial yang ada belum difungsikan dengan baik, padahal lembaga ini merupakan motor penggerak dan penerima aspirasi masyarakat sehingga dapat mendorong perkembangan masyarakat ke arah yang lebih baik. Lembaga sosial yang ada di nagari Batu Banyak adalah badan musyawarah nagari $(\mathrm{BMN})$, lembaga pemberdayaan masyarakat nagari (LPMN), lembaga swadaya masyarakat (LSM), lembaga keamanan masyarakat (LKM), pendidikan kesejahteraan keluarga (PKK), dan karang taruna. Walaupun lembaga sosial banyak namun tidak berfungsi sesuai tugas masing-masing. Lembaga sosial tidak mampu mengcover masyarakat sesuai cita-cita bersama. Hal ini mengakibatkan masyarakat berdiri sendiri-sendiri dan tidak ada alat untuk menyatukan mereka. Sosialisasi yang kurang tentang lembaga sosial membuat masyarakat memiliki pengetahuan yang minim terhadap fungsi dan perannya. Padahal dengan berfungsinya lembaga sosial dapat membentuk sikap dan mental masyarakat yang lebih terbuka sehingga mau menerima perubahan-perubahan yang ada.

\section{c. Budaya}

Menurut Koentjaraningrat (2005:94), kebudayaan merupakan pola-pola gagasan/ide, tindakan, dan hasil kelakuan yang dimantapkan oleh berbagai sistem nilai dan norma. Didalam kebudayaan terdapat komponen-komponen yang harus diperhatikan yaitu sistem budaya (menata dan menetapkan tindakan-tindakan manusia), sistem sosial (interaksi antara individu dan masyarakat), sistem kepribadian (sikap seseorang), dan sistem organisme (pelengkap bagi seluruh kerangka yang melibatkan proses biologi serta bikimia yang terdapat dalam diri manusia). Kebudayaan mengandung sistem nilai budaya yaitu adat istiadat yang merupakan pedoman atau orientasi 
masyarakat dalam kehidupan. Masyarakat Batu Banyak masih mempertahankan adat istiadat minangkabau yang bersifat mengikat. Masyarakat juga memiliki pengetahuan yang minim serta wawasan yang sempit. Hal ini mempengaruhi pola pikir masyarakat yang sulit dalam menerima perubahan-perubahan dari luar. Selain itu, lemahnya hubungan sosial masyarakat mengakibatkan masyarakat berlomba-lomba membeli barang tanpa memperhatikan kebutuhan. Sikap masyarakat yang bersifat konsumtif mengakibatkan masyarakat semakin terpuruk dalam kemiskinan sehingga jalan satu-satunya adalah bergantung pada sumberdaya alam.

\section{d. Lembaga Ekonomi}

Lembaga ekonomi merupakan faktor penunjang dalam menopang perekonomian rakyat. Semakin banyak dan cukup lembaga ekonomi yang ada disuatu daerah maka semakin kuat ekonomi masyarakat. Lembaga ekonomi harus mampu mengayomi masyarakat dalam meningkatkan kesejahteraan hidup. Namun yang menjadi permasalahan di nagari Batu Banyak adalah nagari ini tidak memiliki lembaga ekonomi yang mampu menopang kehidupan masyarakat. Lembaga ekonomi yang ada hanyalah simpan pinjam perempuan dan kelompok tani dengan penyentuhan yang kurang dan sangat terbatas. Nagari Batu Banyak tidak memiliki koperasi, pasar dan lumbung padi nagari. Terbatasnya lembaga ekonomi yang ada mengakibatkan ekonomi masyarakat juga lemah.

\section{Strategi Pengembangan Desa Tertinggal di Nagari Batu Banyak}

Strategi pengembangan desa merupakan upaya dan usaha-usaha dalam mengembangkan desa ke arah yang lebih maju. Dalam strategi pengembangan diperlukan identifikasi potensi desa. Potensi desa berguna dalam menentukan kekuatan, kelemahan, peluang dan ancaman desa sehingga dapat dilakukan strategi yang tepat dalam pengembangan. Untuk mengetahui kekuatan, kelemahan, peluang dan ancaman desa maka peneliti 
melakukan diskusi kelompok terfokus (FGD). Anggota dari diskusi kelompok terfokus adalah tokoh masyarakat Batu Banyak dan orang-orang yang memiliki wawasan serta pengetahuan tentang nagari sehingga diperoleh informasi yang detail, lengkap, dan akurat. Tujuan dilakukannya FGD, untuk memperoleh informasi yang realistis tentang strategi pengembangan desa di nagari Batu Banyak sebab yang paling paham nagari adalah masyarakat itu sendiri. Anggota diskusi memiliki pandangan-pandangannya sendiri terhadap potensi desa yang ada di nagari Batu Banyak.

Berdasarkan hasil diskusi kelompok terfokus, maka diperoleh informasi tentang kekuatan, kelemahan, peluang dan ancaman yang dimiliki oleh nagari Batu Banyak dengan menggunakan analisis SWOT. Strategi yang dilakukan dalam pengembangan nagari Batu Banyak sesuai analisis SWOT adalah dengan memperhatikan empat alternatif SO (strategis ini memanfaatkan seluruh kekuatan dengan memperhatikan peluang), alternatif WO (memanfaatkan kelemahan dengan memperhatikan peluang), alternatif strategis ST (memanfaatkan kekuatan dengan memperhatikan ancaman) dan alternatif WT (memanfaatkan kelemahan dengan memperhatikan ancaman). Untuk lebih jelasnya dapat dilihat pada tabel dibawah ini.

\section{Tabel 3}

Matriks SWOT dalam Strategi Pengembangan Desa Tertinggal di Nagari Batu Banyak Tahun 2012

\begin{tabular}{|l|l|l|}
\hline & Kekuatan (Strengths-S) & Kelemahan (Weaknesses-W) \\
1. Tanah subur dengan & 1. Sumberdaya lahan terbatas. \\
jenis tanah adalah andosol & 2. Kualitas SDM rendah baik \\
& sehingga cocok untuk & masyarakat maupun aparatur \\
pertanian dengan tanaman & pemerintahan nagari. \\
utama adalah padi. & 3. Partisipasi perantau dalam \\
2. Tingginya produksi & pembangunan nagari masih \\
jerami dapat dimanfaatkan & kurang. \\
untuk makanan ternak. & 4. Pengawasan/kontrol \\
3. Air melimpah & pemerintahan terhadap nagari \\
4. Cocok dalam & belum ada. \\
\hline
\end{tabular}




\begin{tabular}{|c|c|c|}
\hline & $\begin{array}{l}\text { pengembangan budidaya } \\
\text { rumput gajah dan } \\
\text { pengembangan usaha } \\
\text { peternakan seperti sapi. } \\
\text { 5. Iklim mendukung. } \\
\text { 6. Jumlah tenaga kerja } \\
\text { banyak. }\end{array}$ & $\begin{array}{l}\text { 5. Penggunaan waktu yang } \\
\text { salah seperti pergi ke sawah } \\
\text { pada siang hari. } \\
\text { 6. Lemahnya kelembagaan dan } \\
\text { organisasi berbasis } \\
\text { masyarakat. } \\
\text { 7. Banyaknya penduduk } \\
\text { miskin. } \\
\text { 8. Sistem pengairan rusak } \\
\text { 9. Mahalnya harga pupuk dan } \\
\text { bibit unggul. } \\
\text { 10. Rendahnya akses jalan } \\
\text { produksi. } \\
\text { 11. Ketergantungan } \\
\text { masyarakat terhadap SDA } \\
\text { masih tinggi. } \\
\text { 12. Pemanfaatan IPTEK masih } \\
\text { rendah. } \\
\text { 13. Adanya tengkulak } \\
\text { mengakibatkan masyarakat } \\
\text { terus dililit utang. } \\
\text { 14. Tidak adanya koperasi. } \\
\text { 15. Pemerintah nagari tidak } \\
\text { mengikutsertakan niniak } \\
\text { mamak dan cadiak pandai } \\
\text { dalam pemerintahan. } \\
\text { 16. Harga beras tidak stabil. }\end{array}$ \\
\hline $\begin{array}{l}\text { Peluang } \\
\text { (Opportuniti } \\
\text { es-O) } \\
\text { 1. Budidaya } \\
\text { peternakan } \\
\text { seperti ikan, } \\
\text { sapi, ayam, } \\
\text { dan itik. } \\
\text { 2. Adanya } \\
\text { penyuluhan- } \\
\text { penyuluhan } \\
\text { pertanian dari } \\
\text { pemerintah. } \\
\text { 3. Bantuan }\end{array}$ & $\begin{array}{l}\text { Srategi SO } \\
\text { 1. Meningkatkan dan } \\
\text { mengoptimalkan hasil } \\
\text { produksi pertanian } \\
\text { khsusunya padi melalui } \\
\text { tanah yang subur } \\
\text { 2. Mengembangkan usaha } \\
\text { peternakan ikan, sapi, } \\
\text { ayam, dan itik serta } \\
\text { memanfaatkan kotoran sapi } \\
\text { untuk pupuk organik. } \\
\text { 3. Peningkatan } \\
\text { pengetahuan masyarakat } \\
\text { melalui penyuluhan }\end{array}$ & $\begin{array}{l}\text { Strategi WO } \\
\text { 1. Memanfaatkan lahan yang } \\
\text { terbatas dengan menggunakan } \\
\text { sistem pertanian tumpang sari } \\
\text { (sawah dengan ikan). } \\
\text { 2. Meningkatkan SDM melalui } \\
\text { penyuluhan dan pelatihan } \\
\text { terutama di bidang pertanian. } \\
\text { 3. Memanfaatkan bantuan } \\
\text { pupuk, bibit unggul dan sapi } \\
\text { dari pemerintah sehingga hasil } \\
\text { pertanian lebih optimal. } \\
\text { 4. Menjalin hubungan } \\
\text { kerjasama dengan perantau }\end{array}$ \\
\hline
\end{tabular}




\begin{tabular}{|c|c|c|}
\hline $\begin{array}{l}\text { sapi, pupuk, } \\
\text { dan bibi } \\
\text { unggul. } \\
\text { 4. Bantuan } \\
\text { pamsimas } \\
\text { (penyedian air } \\
\text { minum dan } \\
\text { sanitasi } \\
\text { berbasis } \\
\text { masyarakat) } \\
\text { dari } \\
\text { pemerintah. } \\
5 . \\
\text { Pengembanga } \\
\text { n mata } \\
\text { pencarian } \\
\text { alternatif } \\
\text { dengan } \\
\text { menjahit. } \\
6 . \\
\text { Pengembanga } \\
\text { n usaha } \\
\text { makanan } \\
\text { ternak. } \\
7 . \\
\text { Mengikutserta } \\
\text { kan perantau } \\
\text { dalam } \\
\text { pembangunan } \\
\text { nagari. } \\
\text {. }\end{array}$ & $\begin{array}{l}\text { pertanian sehingga } \\
\text { masyarakat mampu } \\
\text { menggunakan pupuk dan } \\
\text { bibit unggul. } \\
\text { 4. Memanfaatkan bantuan } \\
\text { pamsimas yang diberikan } \\
\text { pemerintah. } \\
\text { 5. Memanfaatkan air yang } \\
\text { melimpah untuk budidaya } \\
\text { ikan. } \\
\text { 6. Memanfaatkan tanah } \\
\text { kosong untuk budidaya } \\
\text { rumput gajah. } \\
\text { 7. Mengembangkan mata } \\
\text { pencarian alternatif dengan } \\
\text { menjahit. } \\
\text { 8. Memanfaatkan iklim } \\
\text { yang mendukung untuk } \\
\text { menanam sayur-sayuran di } \\
\text { pekarangan rumah. } \\
\text { 9. Memanfaatkan jumlah } \\
\text { tenaga yang banyak dalam } \\
\text { pengembangan usaha } \\
\text { makanan ternak. } \\
\text { 10. Memanfaatkan perantau } \\
\text { dalam pembangunan } \\
\text { nagari. }\end{array}$ & 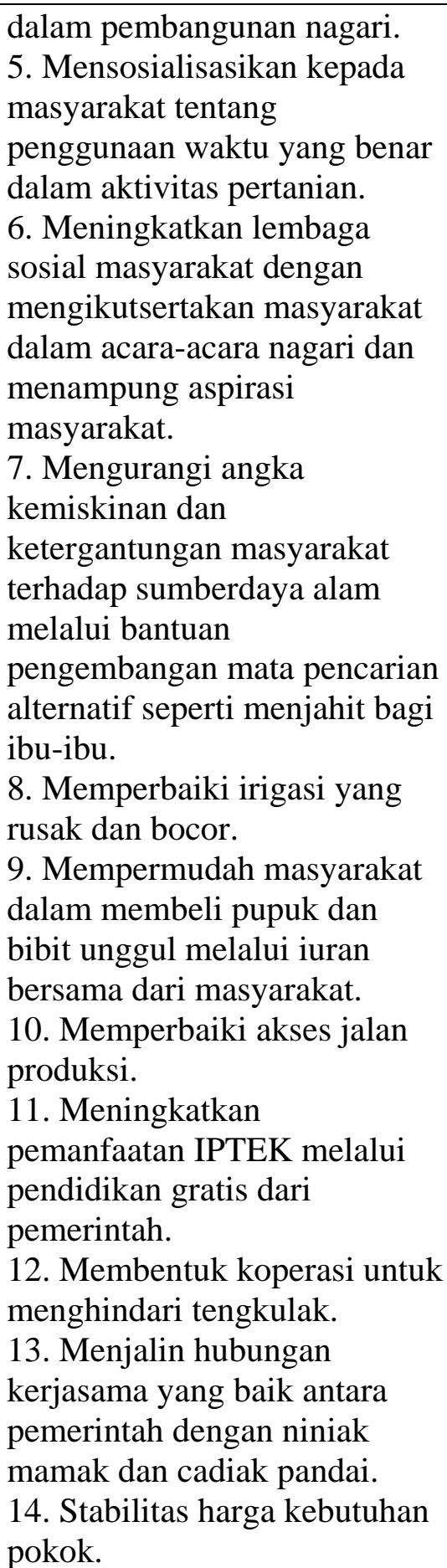 \\
\hline
\end{tabular}




\begin{tabular}{|l|l|l|}
\hline Ancaman & Strategi ST & Strategi WT \\
(Threats-T) & 1. Mencari daerah & 1. Memanfaatkan lahan yang \\
1. Tidak & pemasaran beras & kosong seperi pematang sawah \\
adanya daerah & (marketing) & ditanami sayur-sayuran \\
pemasaran & 2. Sosialisasi tindakan & sehingga lahan yang terbatas \\
beras & ekonomi bermoral & dapat dimanfaatkan secara \\
2. Munculnya & (membeli sesuai kebutuhan & optimal. \\
budaya & bukan keinginan). & 2. Meningkatkan SDM \\
konsumtif. & 3. Meningkatkan sarana & masyarakat agar tidak \\
3. Kesulitan & dan prasarana melalui & menerapkan budaya \\
dalam & bantuan yang diberikan & konsumtif. \\
perolehan & pemerintah (bandes). & 3. Membuka lapangan \\
bibit unggul. & 4. Mengembangkan usaha & pekerjaan dengan tujuan agar \\
4. Sarana dan & peternakan sehingga dapat & generasi muda tidak merantau. \\
prasarana & meningkatkan uang kas & 4. Meningkatkan keamanan \\
terbatas. & nagari. & nagari dengan melakukan \\
5. Sumber & 5. Mengembangkan usaha & ronda malam dan memberikan \\
dana nagari & pertanian dan peternakan & masyarakat tanggungjawab \\
terbatas. & sehingga generasi muda & untuk dapat menjaga \\
6. Banyak & tidak ke perantauan. & lingkungan. \\
generasi muda & 6. Menegakkan peraturan & \\
yang & dengan membuat peraturan & \\
merantau. & nagari sehingga keadaan & \\
7. Peraturan & menjadi nyaman dan & \\
nagari tidak & kondusif. & \\
ada sehingga & & \\
lingkungan & & \\
tidak & & \\
kondusif. & & \\
& & \\
\hline
\end{tabular}

Berdasarkan tabel dapat dijelaskan bahwa strategi yang tepat dalam pengembangan desa tertinggal di nagari Batu Banyak adalah meningkatkan sumberdaya alam melalui intensifikasi pertanian. Intensifikasi pertanian dilakukan dilahan yang sempit sehingga lahan dapat dimanfaatkan secara optimal dengan menggunakan bibit unggul, cara pengolahan yang baik, pengairan/irigasi yang teratur, pemupukan, dan pemasaran (marketing). Oleh 
sebab itu, irigasi harus diperbaiki dan rehabilitas jalan perlu dilakukan sebab irigasi dan jalan merupakan penunjang kegiatan pertanian.

Selanjutnya, meningkatkan sumber daya manusia melalui penyuluhan dan pelatihan dalam bidang pertanian. Menumbuhkan minat masyarakat dalam pendidikan agar berpendidikan lebih tinggi. Pemerintah nagari juga harus memberikan beasiswa bagi pemuda yang berprestasi untuk dapat melanjutkan pendidikan kejenjang yang lebih tinggi. Sedangkan untuk meningkatkan pertumbuhan ekonomi masyarakat harus memiliki mata pencarian alternatif seperti menjahit sehingga masyarakat tidak bergantung kepada sumberdaya alam khususnya sawah. Nagari Batu Banyak juga harus memiliki lembaga ekonomi yang cukup seperti koperasi atau lumbung padi nagari dan lembaga sosial yang berfungsi untuk menampung aspirasi masyarakat sehingga masyarakat dapat berpatisipasi dalam segala bidang.

Menurut Freddy Rangkuti (2002:3) strategi adalah alat yang digunakan untuk mencapai tujuan sehingga dapat menciptakan keunggulan bersaing. Strategi bersifat jangka panjang berupa tindakan dan senantiasa meningkat secara terus menerus tentang apa yang diharapkan untuk masa depan. Bentuk strategi yang digunakan dalam pengembangan desa di nagari Batu Banyak adalah analisis SWOT. Analisis SWOT merupakan alat yang dipakai untuk menyusun strategi pengembangan desa tertinggal dengan membentuk matriks SWOT. Matriks SWOT ini dapat menggambarkan secara jelas bagaimana peluang dan ancaman yang dihadapi sehingga dapat disesuaikan dengan kekuatan serta kelemahan yang dimiliki desa. Melalui matriks SWOT dapat ditetapkan strategi pengembangan yang tepat. Matriks ini menghasilkan empat sel kemungkinan alternatif strategis yaitu SO memanfaatkan seluruh kekuatan dengan memperhatikan peluang, WO memanfaatkan kelemahan dengan memperhatikan peluang, ST adalah memanfaatkan kekuatan dengan 
memperhatikan ancaman, dan WT memanfaatkan kelemahan dengan memperhatikan ancaman.

Strategi yang dilakukan strategi SO adalah meningkatkan dan mengoptimalkan hasil produksi padi dengan memakai bibit unggul, mengembangkan usaha peternakan ikan, sapi, ayam, dan itik serta memanfaatkan kotoran sapi sebagai pupuk organik, peningkatan pengetahuan masyarakat melalui penyuluhan pertanian sehingga masyarakat mampu menggunakan pupuk dan bibit unggul, memanfaatkan bantuan pamsimas yang diberikan pemerintah, memanfaatkan air yang melimpah untuk budidaya ikan, dan memanfaatkan tanah kosong untuk budidaya rumput gajah, mengembangkan mata pencarian alternatif dengan menjahit, memanfaatkan iklim yang mendukung untuk menanam sayur-sayuran di pekarangan rumah, memanfaatkan jumlah tenaga yang banyak dalam pengembangan usaha makanan ternak, serta memanfaatkan perantau dalam pembangunan nagari.

Sedangkan strategi yang dilakukan strategi WO adalah memanfaatkan lahan yang terbatas dengan menggunakan sistem pertanian tumpang sari (sawah dengan ikan), meningkatkan SDM melalui penyuluhan dan pelatihan terutama di bidang pertanian, memanfaatkan bantuan pupuk, bibit unggul dan sapi dari pemerintah sehingga hasil pertanian lebih optimal. Menjalin hubungan kerjasama dengan perantau dalam pembangunan nagari, mensosialisasikan kepada masyarakat tentang penggunaan waktu yang benar dalam aktivitas pertanian. Selanjutnya, meningkatkan lembaga sosial masyarakat dengan mengikutsertakan masyarakat dalam acara-acara nagari dan menampung aspirasi masyarakat. Mengurangi angka kemiskinan dan ketergantungan masyarakat terhadap sumberdaya alam melalui bantuan pengembangan mata pencarian alternatif seperti menjahit bagi ibu-ibu. Memperbaiki irigasi yang rusak dan akses jalan produksi sehingga 
masyarakat tidak kesulitan dalam perolehan air. Mempermudah masyarakat dalam membeli pupuk dan bibit unggul melalui iuran bersama dari masyarakat. Meningkatkan pemanfaatan IPTEK melalui pendidikan gratis dari pemerintah, membentuk koperasi untuk menghindari tengkulak. Menjalin hubungan kerjasama yang baik antara pemerintah dengan niniak mamak dan cadiak pandai serta stabilitas harga kebutuhan pokok.

Strategi ST, memanfaatkan kekuatan dengan memperhatikan ancaman. Usaha-usaha yang dilakukan adalah mencari daerah pemasaran beras (marketing) karena beras Batu Banyak merupakan beras yang berkualitas. Pemerintah nagari juga harus melakukan sosialisasi tindakan ekonomi bermoral (membeli sesuai kebutuhan bukan keinginan) untuk menghindari budaya konsumtif. Strategi lain yang dilakukan adalah meningkatkan sarana dan prasarana melalui bantuan yang diberikan pemerintah (bandes). Mengembangkan usaha peternakan sehingga dapat meningkatkan uang kas nagari. Mengembangkan usaha pertanian dan peternakan sehingga generasi muda tidak ke perantauan. Menegakkan peraturan dengan membuat peraturan nagari sehingga keadaan menjadi nyaman dan kondusif.

Strategi yang dilakukan dalam strategi WT adalah memanfaatkan kelemahan dengan memperhatikan ancaman. Usaha yang dilakukan dalam strategi ini yaitu memanfaatkan lahan yang kosong seperti pekarangan ditanami sayur-sayuran sehingga lahan yang terbatas dapat dimanfaatkan secara optimal, meningkatkan sumberdaya manusia agar tidak menerapkan budaya konsumtif, membuka lapangan pekerjaan dengan tujuan agar generasi muda tidak merantau, serta meningkatkan keamanan nagari dengan melakukan ronda malam dan memberikan masyarakat tanggungjawab untuk dapat menjaga lingkungan.

Menurut Lukman Edy (2009:132), strategi pengembangan desa tertinggal dapat dilakukan dengan rehabilitas dan pembangunan infrastruktur. 
Rehabilitas dan pembangunan infrastruktur bertujuan dalam mengembangkan produktivitas masyarakat dalam bidang ekonomi maupun sosial. Permasalahan yang dihadapi nagari Batu Banyak adalah infrastruktur, seperti irigasi dan jalan banyak yang rusak. Rusaknya infrastruktur di nagari mengakibatkan terhambatnya aktivitas perekonomian masyarakat. Oleh karena itu, perlu dilakukan rehabilitas dan pembangunan infrastruktur di nagari Batu Banyak. Apalagi nagari Batu Banyak merupakan nagari yang kegiatan ekonominya bergerak di bidang pertanian sehingga irigasi dan jalan merupakan dasar utama penggerak kehidupan masyarakat.

Menurut Maksudin (2001:200) strategi pengembangan desa tertinggal dapat dilakukan dengan melakukan pembinaan desa. Pembinaan desa bertujuan untuk mengembangkan potensi desa. Potensi ini dapat berupa meningkatkan potensi sumber daya manusia melalui proses pendidikan dan pembelajaran, meningkatkan potensi sumber daya manusia/lingkungan dengan melaksanakan penyuluhan akan pentingnya kesadaran masyarakat akan pemberdayaan potensi alam dengan mementingkan pemeliharaan, pengolahan, dan pemanfaatan secara optimal berdasarkan asas kebersamaan dan gotong royong. Oleh sebab itu, sumber daya manusia di Batu Banyak harus ditingkatkan agar masyarakat mampu hidup sejahtera dan tidak bergantung terhadap sumberdaya alam.

Selanjutnya, dalam peningkatan SDM diperlukan partisipasi masyarakat dalam mendukung program pemerintah seperti sarjana pelopor nagari. Sarjana pelopor nagari ini merupakan beasiswa yang diberikan pemerintah nagari untuk bisa bersekolah ke perguruan tinggi sehingga setelah tamat nanti dapat mengabdi dan mengaplikasikan ilmunya ke nagari. Oleh karena itu, pemerintah nagari harus memahami dan mengerti tentang kebutuhan, permasalahan, dan aset nagari. Kebutuhan nagari Batu Banyak dalam bidang pendidikan adalah dibutuhkannya SMK pertanian sebab sesuai dengan 
karakteristik lokal. Selain itu, nagari Batu Banyak memiliki jumlah tenaga kerja yang banyak sehingga nanti setelah tamat dapat mengembangkan usaha peternakan, perikanan, dan pertanian sesuai dengan skill yang diperolehnya di SMK tersebut.

Strategi pengembangan yang dilakukan adalah pembaharuan dalam bidang sosial. Menurut Anwar Sitepu (2011:1), strategi yang dilakukan dalam pengembangan desa tertinggal adalah dengan membentuk lembaga kesejahteraan sosial yang berfungsi sebagai wadah agar masyarakat berpartisipasi dalam memberikan kontribusinya terhadap daerah tempat mereka tinggal. Dalam kegiatan ini masyarakat harus aktif dan berpartisipasi dalam program-program lembaga sosial sehingga terjadinya transparansi antara masyarakat dan pemerintah.

Nagari Batu Banyak memiliki banyak lembaga sosial seperti BMN, LPMN, LSM, LKM, PKK, dan karang taruna. Namun lembaga sosial yang ada tidak berfungsi sehingga program-program tidak berjalan sesuai rencana. Sebaiknya dengan beranekaragamnya lembaga sosial di nagari Batu Banyak, masyarakat dapat berpartisipasi dalam memberikan pendapat, ide, gagasan, dan tindakan. Tindakan yang dilakukan agar lembaga dapat berfungsi adalah memberikan sosialisasi kepada masyarakat bahwa lembaga sosial merupakan penggerak dan pendorong pemerintah nagari dalam menjalankan pemerintahan. Meningkatkan kepedulian masyarakat terhadap nagari melalui kegiatan-kegiatan kebersamaan seperti gotong-royong. Kegiatan ini bermanfaat bagi masyarakat agar terjalinnya keterbukaan dan transparansi.

Selain lembaga sosial, lembaga yang harus dikembangkan adalah lembaga ekonomi. Lembaga ekonomi merupakan sarana penunjang kebutuhan hidup masyarakat. Menurut Maksudin (2001:200) strategi yang tepat digunakan adalah meningkatkan potensi ekonomi melalui enterpreuner (wirausaha), penerapan teknologi tepat guna, pola tanam yang memadai 
sehingga mampu membangun potensi ekonomi berdasarkan pembangunan ekonomi berbasis rakyat yang ditekankan pada pembentukan masyarakat islami. Usaha-usaha ini harus dilakukan untuk kemajuan nagari Batu Banyak. Jika kegiatan tersebut dapat dilakukan maka pertumbuhan ekonomi akan meningkat.

\section{PENUTUP}

1. Permasalahan nagari Batu Banyak dari potensi fisik adalah lahan terbatas, terjadinya proses pembiaran dalam penggunaan lahan sebab status lahan merupakan milik kaum yang pemanfaatan harus dimusyawarahkan dengan kaum, pengetahuan masyarakat dalam bidang pertanian masih rendah serta infrastruktur seperti irigasi dan jalan rusak.

2. Permasalahan dari potensi non fisik adalah kualitas sumber daya manusia yang rendah. Rata-rata tingkat pendidikan masyarakat Batu Banyak adalah tamatan SD dan SMP.

3. Strategi pengembangan nagari Batu Banyak menggunakan analisis SWOT yaitu dengan meningkatkan dan mengoptimalkan sumber daya alam melalui pemakaian bibit unggul, cara pengolahan yang baik, pemakaian pupuk secara teratur, memperbaiki irigasi dan akses jalan produksi, mencari daerah-daerah pemasaran, dan meningkatkan sektor peternakan dengan budidaya peternakan sapi ataupun ikan. Meningkatkan sumber daya manusia melalui penyuluhan dan pelatihan-pelatihan dibidang pertanian, sosialisasi IPTEK, mendorong dan memotivasi generasi muda agar melanjutkan sekolah ke jenjang yang lebih tinggi, membuat peraturan nagari agar masyarakat hidup disiplin, memberikan beasiswa kepada siswa yang berprestasi, sosialisasi fungsi dan peran lembaga sosial agar masyarakat berpartisipasi dalam pembangunan nagari, menjalin hubungan kerjasama yang baik antara pemerintahan 
nagari, cadiak pandai, niniak mamak dan masyarakat agar lebih transparan dan jelas. Melibatkan masyarakat dalam kegiatan yang berhubungan dengan nagari sehingga terjalin kekompakan, serta sosialisasi tindakan ekonomi bermoral (membeli sesuatu sesuai kebutuhan bukan keinginan), dan mendirikan koperasi ataupun lumbung padi nagari untuk kesejahteraan hidup masyarakat.

\section{DAFTAR PUSTAKA}

Anwar Sitepu. 2011. "Konstruksi Lembaga Kesejahteraan Sosial Untuk Pemberdayaan Masyarakat Dalam Rangka Penanggulangan Kemiskinan”. Jurnal Penelitian dan Pengembangan Kesejahteraan Sosial. Volume 16 No. 1 Januari - April 2011.

Dirjen Pemberdayaan Masyarakat dan Desa. 2007. Indonesia : Departemen Dalam Negeri.

Freddy Rangkuti. 2002. Analisis SWOT Teknik Membedah Kasus Bisnis. Jakarta : Gramedia Pustaka Utama.

Keputusan Menteri No. 1 Tahun 2005 tentang Pembangunan Desa Tertinggal. Online diakses 20 Agustus 2013.

Koentjaraningrat. 2000. Kebudayaan Mentalitas dan Pembangunan. Jakarta : Penerbit PT Gramedia Pustaka Umum.

Koentjaraningrat. 2005. Pengantar Antropologi. Jakarta : PT Rineka Cipta.

Koestoer, dkk. 1995. Perspektif Lingkungan Desakota : Teori dan Kasus. Jakarta : UI Press.

Lukman Edy. 2009. Pencapaian Pembangunan Daerah Tertinggal Lima Tahun Terakhir. Jurnal Sekretariat Negara RI | No. 13 | Agustus 2009.

Maksudin. 2001. Strategi Pengembangan Potensi dan Program Desa Binaan/Mitra Kerja IAINSunan Kalijaga Yogyakarta. Aplikasia : Jurnal Aplikasi llmu-ilmuAgama,Vol.11,No. 2 Desember 2001:197-211.

Suhardjo. 2008. Geografi Pedesaan Sebuah Antologi. Yogyakarta : Ideas Media. 